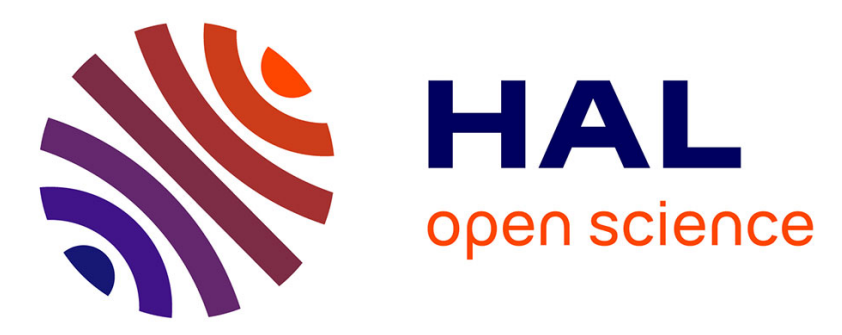

\title{
Radiolabelling of the octadentate chelators DFO* and oxoDFO* with zirconium-89 and gallium-68
}

Marie Brandt, Joseph Cowell, Margaret L Aulsebrook, Gilles Gasser, Thomas L Mindt

\section{- To cite this version:}

Marie Brandt, Joseph Cowell, Margaret L Aulsebrook, Gilles Gasser, Thomas L Mindt. Radiolabelling of the octadentate chelators DFO* and oxoDFO* with zirconium-89 and gallium-68. Journal of Biological Inorganic Chemistry, 2020, 25 (5), pp.789-796. 10.1007/s00775-020-01800-4 . hal-02971599

\section{HAL Id: hal-02971599 \\ https://hal.science/hal-02971599}

Submitted on 19 Oct 2020

HAL is a multi-disciplinary open access archive for the deposit and dissemination of scientific research documents, whether they are published or not. The documents may come from teaching and research institutions in France or abroad, or from public or private research centers.
L'archive ouverte pluridisciplinaire HAL, est destinée au dépôt et à la diffusion de documents scientifiques de niveau recherche, publiés ou non, émanant des établissements d'enseignement et de recherche français ou étrangers, des laboratoires publics ou privés. 


\section{Radiolabelling of the Octadentate Chelators DFO* and oxoDFO* with Zirconium-89 and Gallium-68}

Marie Brandt ${ }^{1,2}$, Joseph Cowell ${ }^{3}$, Margaret L. Aulsebrook ${ }^{3}$, Gilles Gasser ${ }^{3 *}$, Thomas L. Mindt ${ }^{1,2,4 *}$

${ }^{1}$ Ludwig Boltzmann Institute Applied Diagnostics, General Hospital of Vienna, Währinger Gürtel 18-20, A-1090 Vienna, Austria.

2 Department of Biomedical Imaging and Image Guided Therapy, Division of Nuclear Medicine, Medical University of Vienna, Währinger Gürtel 18-20, A-1090 Vienna, Austria.

${ }^{3}$ Chimie ParisTech, PSL University, CNRS, Institute of Chemistry for Life and Health Sciences, Laboratory for Inorganic Chemical Biology, F-75005 Paris, France.

${ }^{4}$ Institute of Inorganic Chemistry, Department of Chemistry, University of Vienna, Währinger Straße 42, A-1090 Vienna, Austria.

*Corresponding Authors: Dr. Gilles Gasser, gilles.gasser@chimieparistech.psl.eu; Prof. Dr. Thomas L. Mindt, Thomas.Mindt@lbiad.lbg.ac.at.

ORCID Numbers

Marie Brandt: 0000-0001-8685-7352

Joseph Cowell: 0000-0001-8750-7223

Margaret L. Aulsebrook: 0000-0002-3323-7288

Gilles Gasser: 0000-0002-4244-5097

Thomas L. Mindt: 0000-0002-2090-1725

\section{Acknowledgements}

This work was funded by the Swiss National Science Foundation (grant Nr. SNSF 205321_157216 to G.G. and T.L.M). The authors thank Katarina Benčurová (Ludwig Boltzmann Institute Applied Diagnostics) and Jonas Aronow (Medical University of Vienna) for technical assistance. 


\section{Abstract}

In recent years, clinical imaging with zirconium-89 $\left({ }^{89} \mathrm{Zr}\right)$-labelled monoclonal antibodies (Ab) by positron emission tomography (immunoPET) has been gaining significant importance in nuclear medicine for the diagnosis of different types of cancer. For complexation of the radiometal ${ }^{89} \mathrm{Zr}$ and its attachment to the $\mathrm{Ab}$, chelating agents are required. To date, only the hexadentate chelator desferrioxamine (DFO) is applied in the clinic for this purpose. However, there is increasing preclinical evidence that the $\left.{ }^{89} \mathrm{Zr}\right] \mathrm{Zr}$-DFO complex is not sufficiently stable and partly releases the radiometal in vivo due to the incomplete coordination sphere of the metal. This leads to unfavourable unspecific uptake of the osteophilic radiometal in bones, hence decreasing the signal-to-noise-ratio and leading to an increased dose to the patient. In the past, several new chelators with denticities $>6$ have been published, notably the octadentate DFO derivative DFO*. DFO* however shows limited water solubility, wherefore an oxygen containing analogue, termed oxoDFO*, was developed in 2017. However, no data on the suitability of oxoDFO* for radiolabelling with ${ }^{89} \mathrm{Zr}$ has yet been reported. In this proofof-concept study, we present the first radiolabelling results of the octadentate, water-soluble chelator oxoDFO*, as well as the in vitro stability of the resulting complex [ ${ }^{89} \mathrm{Zr}$ ] Zr-oxoDFO* in comparison to the analogous octadentate, but less water soluble derivative DFO* and the current "standard" chelator DFO. In addition, the suitability of DFO* and oxoDFO* for radiolabeling with the short-lived PET metal gallium-68 is discussed.

Keywords: chelators; zirconium-89; gallium-68; positron emission tomography (PET) 


\section{Introduction}

Radiolabelled antibodies ( $\mathrm{Ab}$ ) have become an indispensable tool in nuclear medicine for the diagnosis (imaging) of tumours due to their excellent specificity towards various antigens important in oncology.[1] In particular, the number of applications of Abs labelled with positron emitting radionuclides (immunoPET) is steadily increasing.[2,3] Several immunoPET agents are currently being evaluated in clinical trials.[4-7] In general, such agents consist of a tumour-targeting monoclonal $\mathrm{Ab}$ functionalised with a chelator carrying a positron emitting radiometal.

Abs exhibit slow pharmacokinetics and the time until a sufficient accumulation in the target is achieved, can take days to weeks.[8] In the context of nuclear imaging, this results in the necessity of radionuclides with a matching physical half-life, e.g., zirconium-89 $\left({ }^{89} \mathrm{Zr}, \mathrm{t}_{1 / 2}=\right.$ $78.41 \mathrm{~h}) \cdot[9,10]$ The only chelator currently used in clinical trials utilizing ${ }^{89} \mathrm{Zr}$-labelled Abs is the siderophore desferrioxamine (DFO 1, Figure 1). However, the hexadentate chelator DFO 1 is not ideal for the complexation of zirconium since the metal ion mostly has coordination numbers $>6[11,12]$. Therefore, a chelator with a higher denticity, e.g., hepta- or octadentate, would be the more optimal choice. It has been suggested that the unsaturated coordination sphere of zirconium in complexes with DFO results in slow release of zirconium in vivo. This in turn leads to nonspecific uptake of the osteophilic radiometal in bones, an increased background in the PET image, and an additional unnecessary radiation dose to the patient.[5,13] As a consequence, several octadentate chelating systems for the stable complexation of ${ }^{89} \mathrm{Zr}$ have been reported in the recent past. $[14,12,15,16]$ Several of these new chelating systems utilize 4 hydroxamate moieties for octadentate chelation of the radiometal in order to minimize the transchelation rate in vivo. A promising chelator of this series is an octadentate version of DFO, termed DFO* 2 (Figure 1).[17] It has been shown that DFO* 2 
forms more stable complexes with ${ }^{89} \mathrm{Zr}$ than DFO 1 in vitro and in vivo. In a direct comparison of ${ }^{89} \mathrm{Zr}$ ]Zr-DFO-trastuzumab with analogous [ $\left.{ }^{89} \mathrm{Zr}\right] \mathrm{Zr}$-DFO*-trastuzumab in a N87-tumour mouse model, it was shown that the application of DFO* 2 led to significantly less nonspecific uptake of radioactivity in bone structures as well as in the skin, liver, spleen, and ileum.[18] Also, the superiority of DFO* 2 in comparison to DFO 1 and DFO-squaramide[19] for late time point PET imaging was demonstrated in primates utilizing a humanized IgG Ab against the herpes simplex viral protein gD.[20] Based on published preclinical data, it has been concluded that DFO* $\mathbf{2}$ is a significant improvement to the commonly applied DFO 1.

A potential limitation of DFO* $\mathbf{2}$ is represented by its low solubility in water. This in turn could interfere with the conjugation of the chelator to proteins that are affected in their binding and folding behaviour by the presence of higher concentrations of organic co-solvents, such as for example human serum albumin[21] or G10 antibodies[22]. Consequently, three water-soluble versions of DFO* 2 with oxygen-containing backbones were published independently by two groups in 2017 and 2020. Codd and co-workers reported a biosynthetic approach using Streptomyces pilosus that provides small amounts of a water-soluble version of DFO* $\mathbf{2}$ with four oxygen atoms in the ligand scaffold.[23] Three years later, the octadentate ligand DFOB$\mathrm{PPH}^{\mathrm{N}} \mathrm{O}^{\mathrm{C}} \mathrm{O}$ with two oxygen atoms in the ligand backbone, synthesized from readily available desferrioxamine, was published by the same group.[24] Alternatively, we employed a solidphase synthesis for the potentially large scale preparation of oxoDFO* 3 (Figure 1). Using the shake-flask-method, $\log D_{7.4}$ values of -1.5 for oxoDFO* 3 and -2.1 for the corresponding zirconium complex ${ }^{\text {nat}} \mathrm{Zr-oxoDFO*} \mathbf{3}$ were determined.[25] In comparison, the published logD value for DFO* 2 is $\log D_{7.4}=-0.4397$.[25] Very recently, a theoretical study by Holland was published predicting that oxoDFO* 3 is an excellent candidate for the stable complexation of zirconium with an estimated thermodynamic stability constant of $\log \beta=54.16 .[26]$ 
Here, we present the first ${ }^{89} \mathrm{Zr}$-labelling of the water-soluble, octadentate chelator oxoDFO* 3. In addition, we were interested in exploring the utility of our DFO* and oxoDFO* chelators for the chelation of other radiometals. In that regard, we also report the results of our investigation into the ability of DFO* 2 and oxoDFO* 3 to complex the radiometal gallium-68 $\left({ }^{68} \mathrm{Ga}, \mathrm{t}_{1 / 2}=67.7 \mathrm{~min}\right)$.<smiles></smiles>

DFO 1 (hexadentate)<smiles>CC(=O)N(O)CCCCCNC(=O)CCC(=O)N(O)CCCCCNC(=O)CCC(=O)N(O)CCCCCNC(=O)CCC(=O)N(O)CCCCCN</smiles>
DFO* 2 (octadentate)<smiles>NCCOCCN(O)C(=O)CCC(=O)NCCOCCN(O)C(=O)CCC(=O)NCCOCCN(O)C(=O)CCC(=O)NCCOCCN(O)C(=O)CCC(N)=O</smiles>

Figure 1. Hexadentate DFO 1 and its octadentate analogues DFO* 2 and oxoDFO* 3.

\section{Experimental Section}

\section{Materials and Methods}

All chemicals and solvents were obtained from commercial sources and used as received.

Millipore water (Milli $Q^{\circledR}$ 8/16 Direct System, Merck) and ethanol (gradient grade $\geq 99 \%$, Sigma-Aldrich) were used for HPLC. DFO 1 (mesylate salt) was purchased from Sigma Aldrich. DFO* 2 and oxoDFO* 3 as well as the corresponding ${ }^{89} \mathrm{Zr}$ - and non-radioactive zirconium ( ${ }^{\text {nat }} \mathrm{Zr}$ ) 
complexes were synthesized according to previously published methods.[25,17] ${ }^{89} \mathrm{Zr}$ was obtained in $0.1 \mathrm{M}$ oxalic acid as $\left[{ }^{89} \mathrm{Zr}\right] \mathrm{Zr}$-oxalate $\left({ }^{89} \mathrm{Zr}\right.$-oxalate) from Perkin Elmer in medical quality. $\left[{ }^{68} \mathrm{Ga}\right] \mathrm{GaCl}_{3}\left({ }^{68} \mathrm{GaCl}_{3}\right.$, ca. $\left.1-1.5 \mathrm{GBq}\right)$ was eluted from an IRE Elit GalleEo ${ }^{\text {TM }}{ }^{68} \mathrm{Ge} /{ }^{68} \mathrm{Ga}$ generator (Fleurus) with $0.1 \mathrm{M} \mathrm{HCl}$ according to the procedure recommended by the manufacturer. The eluate (450-550 MBq in $1.1 \mathrm{~mL}$ ) was collected in an evacuated vial and used without any further processing.

ESI-MS spectra were recorded with a ThermoFisher Scientific LTQ-Orbitrap Velos. RadioTLC was performed using either iTLC plates (glass fibre, impregnated with silica gel, Varian) or RPTLC plates (silica gel 60 RP-18 on aluminium, Merck) with the solvent system indicated in the description of individual experiments.[27] RadioTLC images for quantification were obtained using a Packard Instant Imager (measurement time: 1 min).

High performance liquid chromatography (HPLC) was conducted with a Chromaster preassembled system equipped with a 5160 pump and a 5140 UV detector (Hitachi / VWR). RadioHPLC was performed on a Merck Hitachi L-6200A intelligent pump with a Merck Hitachi UV detector L-7400 and a Packard Radiomatic Flo-One Beta detector equipped with a BGO cell for the detection of radioactivity. For all HPLC analyses, a Synergi Fusion column (RP, $4 \mu, 80$ $\AA ̊ 丿, 30 \times 2 \mathrm{~mm}$, Phenomenex) was used under isocratic conditions (5\% Ethanol / $20 \mathrm{mM}$ phosphate buffer, $\mathrm{pH}$ 7) with a flow rate of $0.4 \mathrm{~mL} / \mathrm{min}$ and a UV wavelength of $220 \mathrm{~nm}$.

\section{Radiosyntheses}

${ }^{89} \mathrm{Zr}$-labelling reactions were carried out by adapted published methods. $[17,18]$ In brief, stock solutions of the chelators (1 mM) were prepared in water (DFO 1, oxoDFO* 3 ) or DMSO (DFO* 2). ${ }^{89} \mathrm{Zr}$-oxalate (20-30 MBq) was transferred to a LoBind Eppendorf ${ }^{\circledast}$ flask and diluted with $0.1 \mathrm{M}$ oxalic acid ( $\mathrm{pH}$ 1) to a total volume of $200 \mu \mathrm{L} .90 \mu \mathrm{L} \mathrm{Na}_{2} \mathrm{CO}_{3}(2 \mathrm{M})$ solution was added 
and the mixture was left standing for 3 min at room temperature (RT, $\mathrm{pH} \mathrm{6-7).} \mathrm{2-50} \mu \mathrm{L}$ of chelator stock solutions $(2-50 \mathrm{nmol})$ was diluted with water to a volume of $200 \mu \mathrm{L}$ and added to the neutralized solution of ${ }^{89} \mathrm{Zr}$. HEPES buffer $(0.5 \mathrm{M}, \mathrm{pH} 7.4)$ was added to a final volume of $1 \mathrm{~mL}$ (resulting in final precursor concentrations of 2-50 $\mu \mathrm{M}$ ) and the mixture was incubated at RT for up-to $2 \mathrm{~h}$. The progress of the reaction was monitored by iTLC (Figure S2) and RP-TLC (Figure S3) with citrate buffer $(0.1 \mathrm{M}, \mathrm{pH} 4)$ as mobile phase.

For ${ }^{68} \mathrm{Ga}$-labelling reactions, $3.3 \mu \mathrm{L}$ of stock solutions of DFO $\mathbf{1}, \mathrm{DFO} * \mathbf{2}$ and oxoDFO* $\mathbf{3}$ (3.3 nmol),) were diluted with either $300 \mu \mathrm{L}$ HEPES buffer (0.5 M, pH 7.4) or HEPES buffer (1.5 $\mathrm{M}, \mathrm{pH} 4.5$ ) in a LoBind Eppendorf ${ }^{\circledast}$ flask, resulting in a final precursor concentration of $10 \mu \mathrm{M}$. $20 \mu \mathrm{L}^{68} \mathrm{GaCl}_{3}(50-200 \mathrm{MBq})$ were added to each vial. Radiolabelling reactions were performed at RT for $2 \mathrm{~h}$ or in a heating block at $95{ }^{\circ} \mathrm{C}$ for $10 \mathrm{~min}$. The progress of the reactions was monitored with iTLC and $0.05 \mathrm{M}$ EDTA pH 4.5 as mobile phase. $\mathrm{R}_{\mathrm{f}}\left({ }^{68} \mathrm{Ga}-\mathrm{EDTA}=1 ;{ }^{68} \mathrm{Ga}-\mathbf{1 , 2 , 3}=\right.$ 0.

\section{Transchelation Experiments}

The ${ }^{89} \mathrm{Zr}$ - and ${ }^{68} \mathrm{Ga}$-complexes of DFO 1, DFO* 2 and oxoDFO* 3 were prepared with a chelator concentration of $10 \mu \mathrm{M}$ in HEPES buffer as described above ( $2 \mathrm{~h}$ at $\mathrm{RT}$ for ${ }^{89} \mathrm{Zr}$ and $10 \mathrm{~min}$ at $95^{\circ} \mathrm{C}$ for ${ }^{68} \mathrm{Ga}$ ). $10 \mu \mathrm{L}$ of the solutions were transferred to LoBind Eppendorf ${ }^{\oplus}$ tubes containing $200 \mu \mathrm{L}$ of solutions of DTPA (5 or $50 \mathrm{mM}$, corresponding to $10^{4}$ and $10^{5}$ fold excess DTPA, respectively) and gently shaken at $\mathrm{RT}$ (final $\mathrm{pH}$ 6). RadioTLC (iTLC) of the reaction mixtures were performed at different time points to determine the transchelation of the radiometals to the challenging chelator DTPA (mobile phase for ${ }^{89} \mathrm{Zr}: 0.05 \mathrm{M}$ DTPA, pH 5; for ${ }^{68} \mathrm{Ga}: 0.05 \mathrm{M}$ EDTA, pH 4.5).[28] 


\section{Results and Discussion}

\section{Radiolabelling Reactions}

First ${ }^{89} \mathrm{Zr}$-labelling reactions were carried out at different concentrations of oxoDFO* 3 using reported reaction conditions.[29,17] We found that an oxoDFO* 3 concentration of approximately $10 \mu \mathrm{M}$ resulted in quantitative complexation of ${ }^{89} \mathrm{Zr}(\approx 20-30 \mathrm{MBq})$ at RT within $2 \mathrm{~h}$ (Figure 2B). Similar results have been reported for DFO 1 and DFO* 2[17] and have been reproduced in this work as well. Importantly, the applied conditions (RT, pH 7.4) are suitable and also used by default for the ${ }^{89} \mathrm{Zr}$-labeling of proteins, e.g., Abs.[18,29] The chemical identity of the formed complex ${ }^{89} \mathrm{Zr}-3$ was confirmed by HPLC comparison with the nonradioactive reference compound natZr-3 (Figures 3 and S1).[25] It should be noted that the broad peaks seen in the HPLC trace are due to an isocratic mobile phase. Application of standard reversed phase (RP) HPLC columns failed to separate the compounds, wherefore a special reversed phase/borderline ion exchange (Synergi Fusion, also see Supporting Information) phase had to be used. The broad peaks do not indicate the formation of multiple isomers. The identity of nat $\mathrm{Zr}-3$ was confirmed by LRMS $\left(\mathrm{m} / \mathrm{z}_{\text {calculated }}=912.29[\mathrm{M}+\mathrm{H}]^{+}, \mathrm{m} / \mathrm{z}_{\text {observed }}\right.$ = 912.37; $[\mathrm{M}+\mathrm{H}]^{+}$, Figure S4).

Next, we looked into the radiolabelling kinetics in more detail. Shortly after the start of the reaction, a transient intermediate, which was not further characterized, formed in minor amounts as detected by iTLC ( $R_{f}{ }^{89} \mathrm{Zr}$-intermediate $=0.2$; not observed by RP-TLC). This intermediate converted slowly to the desired radiometal complex $\left(R_{f}{ }^{89} \mathrm{Zr}-3=0\right)$ within $60 \mathrm{~min}$ and without release of ${ }^{89} \mathrm{Zr}$ ( $\left(R_{f}\right.$ free ${ }^{89} \mathrm{Zr}^{4+}$ as its citrate $=0.8-1$, Figure S3). Deri et al. have reported similar observations during ${ }^{89} \mathrm{Zr}$-labeling studies of the chelator HOPO.[28] They suggested that the intermediate might correspond to an initially formed kinetic product, which reacts further to the thermodynamically stable final complex.[28] The transient 
intermediate formed is rapidly and fully converted to the desired radiolabelled product within $2 \mathrm{~h}$, wherefore its appearance was not considered as a limitation for applications. The clean formation of desired product ${ }^{89} \mathrm{Zr}-3$ with a radiochemical yield (RCY) of $\geq 97 \%$ after approximately $90-120$ min could be confirmed. Figure $2 \mathrm{~A}$ shows the formation of ${ }^{89} \mathrm{Zr}-3$ (red curve) as well as the formation of the intermediate (dots) and its conversion to ${ }^{89} \mathrm{Zr}$-3. The radiolabelling efficiency and achievable molar activity (up to $3 \mathrm{GBq} / \mu \mathrm{mol}$ ) was comparable to those of the reported analogous chelator DFO*2.[30] Since oxoDFO* 3 was primarily designed for a combination with temperature sensitive proteins, kinetic studies were only performed at room temperature.

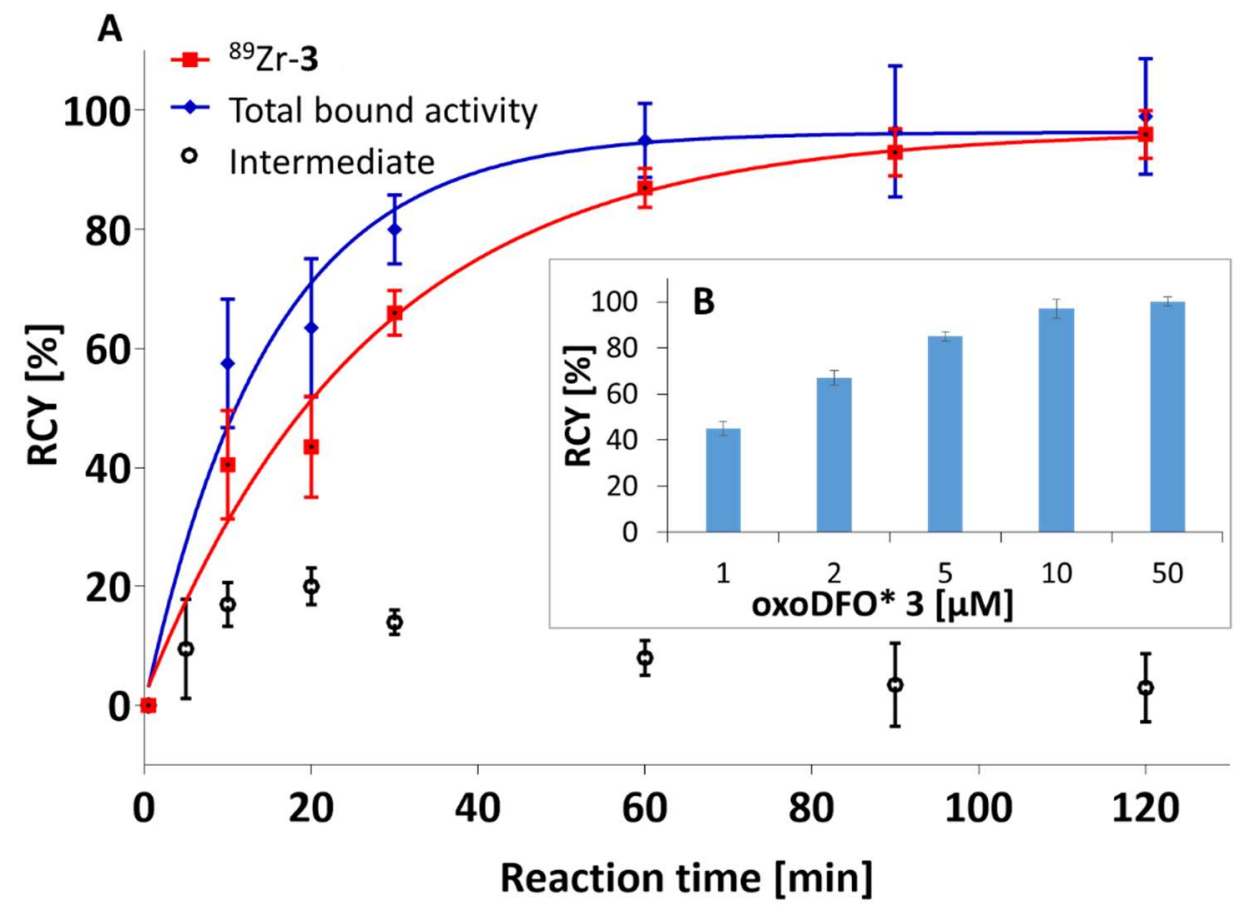

Figure 2. A) Formation of ${ }^{89} \mathrm{Zr}-3$ using $10 \mu \mathrm{M}$ precursor at RT in HEPES (pH 7.4, RT, $\mathrm{n}=3$ ); B) $\mathrm{RCY}$ for the radiolabelling of oxoDFO* 3 with ${ }^{89} \mathrm{Zr}$-oxalate at different concentrations of oxoDFO* 3 after a reaction time of $2 \mathrm{~h}$ at RT $(n=2-3)$. The blue curve indicates the sum of the intermediate and ${ }^{89} \mathrm{Zr}-\mathbf{3}$. 


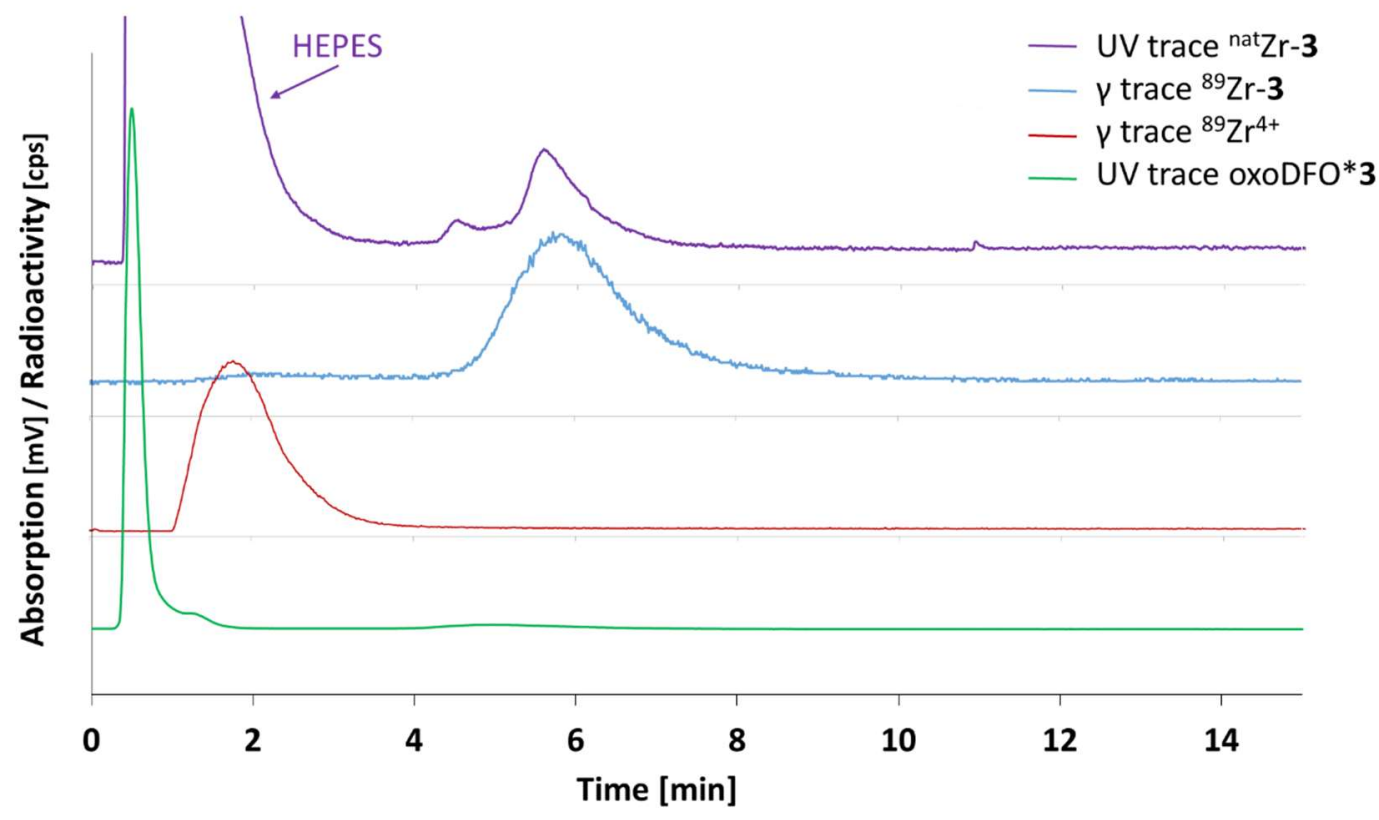

Figure 3. HPLC-chromatograms of oxoDFO* $3,{ }^{89} \mathrm{Zr}^{4+}$, nat $\mathrm{Zr}-3$ and ${ }^{89} \mathrm{Zr}-\mathbf{3}$. The identity of nat $\mathrm{Zr}-\mathbf{3}$ (peak at $R_{t}=5.9 \mathrm{~min}$ ) was also confirmed by mass spectrometry. Slightly different $R_{\mathrm{t}}$-values is the result of the serial arrangement of the $\gamma$ - and UV-detectors. UV traces were measured at $\lambda=220 \mathrm{~nm}$.

\section{Assessment of the Stability of ${ }^{89} \mathrm{Zr}$-Complexes}

To evaluate the stability of the ${ }^{89} \mathrm{Zr}$-complexes of DFO $\mathbf{1}$, DFO* $\mathbf{2}$, and oxoDFO* $\mathbf{3}$, they were incubated at RT and $\mathrm{pH} 6$ with an excess of DTPA ( $5 \mathrm{mM}$ or $50 \mathrm{mM}$ ). We chose a slightly acidic $\mathrm{pH}$ because ${ }^{89} \mathrm{Zr}$-DFO has been reported to be more stable under these conditions.[28] The extent of transchelation of ${ }^{89} \mathrm{Zr}$ was determined by TLC at different time points up to $48 \mathrm{~h}$ ( $\mathrm{R}_{\mathrm{f}}$ $\left.{ }^{89} \mathrm{Zr}-\mathrm{DTPA}=0.9-1, \mathrm{R}_{\mathrm{f}}{ }^{89} \mathrm{Zr}-\mathbf{1 , 2 , 3}=\mathbf{0}\right)$. The experiments performed with $5 \mathrm{mM}$ of DTPA indicated superior stability of ${ }^{89} \mathrm{Zr}-\mathbf{2}$ or $\mathbf{3}$ in comparison to ${ }^{89} \mathrm{Zr}-\mathbf{1}$. While $\left[{ }^{89} \mathrm{Zr}\right] \mathrm{Zr}-\mathrm{DFO} *\left({ }^{89} \mathrm{Zr}-\mathbf{2}\right)$ and ${ }^{89} \mathrm{Zr}-\mathbf{3}$ were stable in the presence of $5 \mathrm{mM}$ DTPA over a time period of $48 \mathrm{~h}, 50 \%$ of ${ }^{89} \mathrm{Zr}$ ]Zr-DFO $\left({ }^{89} \mathrm{Zr}\right.$-1) converted to ${ }^{89} \mathrm{Zr}$-DTPA within $24 \mathrm{~h}$ (Figure 4). Even though transchelation was observed for all ${ }^{89} \mathrm{Zr}$-complexes at the higher concentration of DTPA of $50 \mathrm{mM}$, octadentate DFO* 2 and oxoDFO* 3 clearly formed the more stable complexes with ${ }^{89} \mathrm{Zr}$ than hexadentate DFO 1. These results are in agreement with previously published data[17] and reflect the 
increased stability of Zr-complexes as a result of octadentate coordination of the metal. Furthermore, the challenging experiments at $50 \mathrm{mM}$ allowed for the determination of the stabilities of ${ }^{89} \mathrm{Zr}$-2 or $\mathbf{3}$, relative to one another. Interestingly, ${ }^{89} \mathrm{Zr}-\mathbf{3}$ exhibited slightly improved stability at the higher concentration of DTPA than ${ }^{89} \mathrm{Zr}-\mathbf{2}$ in these experiments. Since the benefit of the improved stability of ${ }^{89} \mathrm{Zr}-2$ has already been demonstrated in mice and primates, $[18,20]$ the analogous, water-soluble chelator oxoDFO* 3 is likely to be suitable for in vivo applications as well.

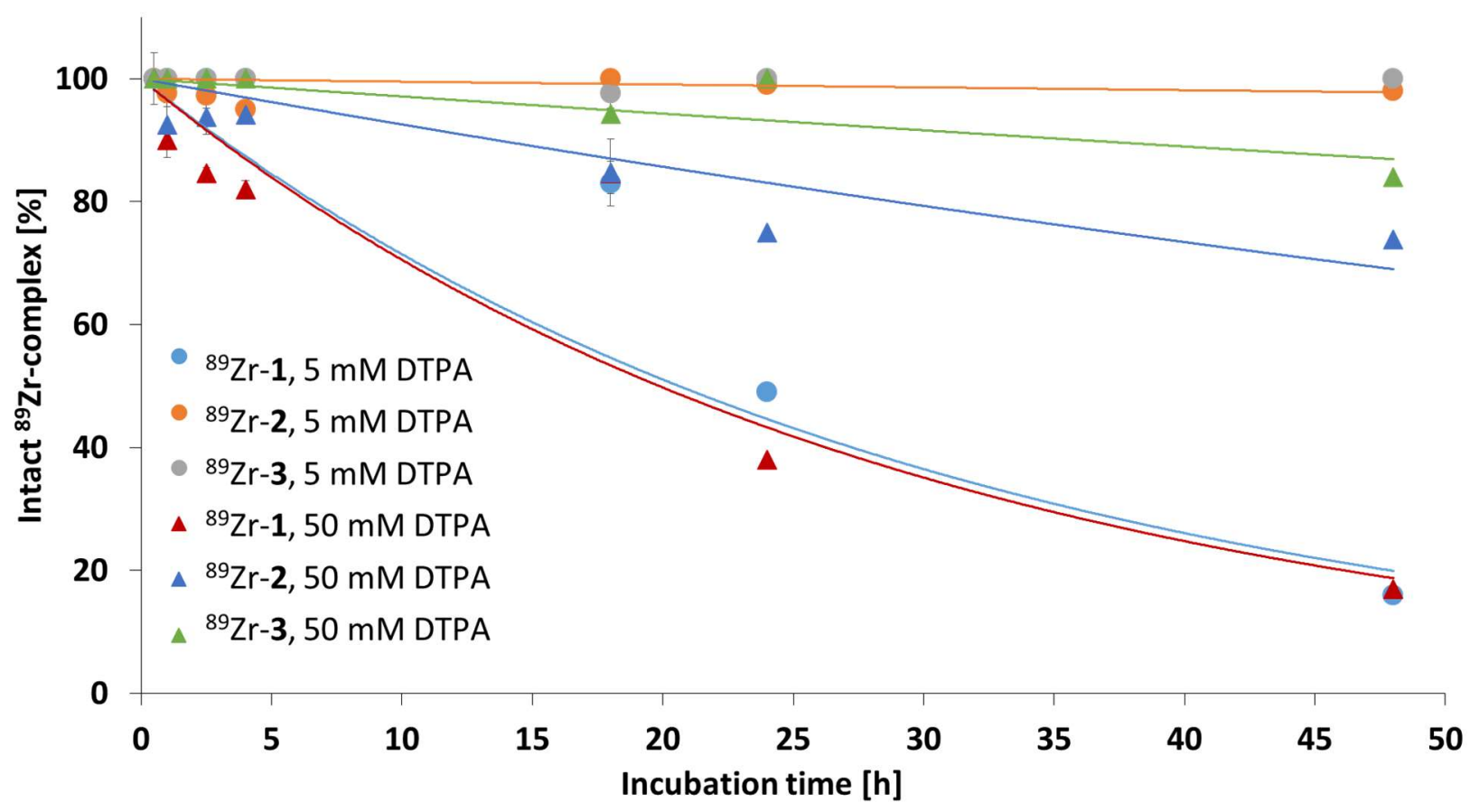

Figure 4. Transchelation curves for ${ }^{89} \mathrm{Zr}-1,2,3$ measured in $5 \mathrm{mM}$ and $50 \mathrm{mM}$ DTPA at pH 6 and RT. Data points of ${ }^{89} \mathrm{Zr}-2$ (orange line) and ${ }^{89} \mathrm{Zr}-3$ (grey line) are overlapping; $n=2-3$. These results are additionally summarized in a table, which can be found in the supporting material.

\section{${ }^{68}$ Ga-Labeling Experiments}

Hydroxamate-containing ligands have also found applications in combination with other (PET) radiometals. ${ }^{[31-33]}$ In particular, complexes of DFO 1 with ${ }^{68} \mathrm{Ga}$ have been used for the labelling of affibodies ${ }^{[34]}$ and peptides ${ }^{[35,36]}$ as well as for infection imaging. ${ }^{[37,38]}$ This is despite the fact that the stability of ${ }^{68} \mathrm{Ga}$-DFO has been the subject of contradictory discussions.[35] To further 
study the utility of our DFO* 2 and oxoDFO* 3 chelators, we decided to evaluate their suitability as ${ }^{68} \mathrm{Ga}$ chelators. ${ }^{68} \mathrm{Ga}$-labelling experiments were performed at different $\mathrm{pH}$ and temperatures and the stability of the ${ }^{68} \mathrm{Ga}$-complexes formed were studied. HEPES was chosen as a buffer at two different $\mathrm{pH}$ values $(\mathrm{pH} 4.5$ and 7.4$)$ due to its favourable properties to reduce the formation of ${ }^{68} \mathrm{Ga}$-colloids[39] and in accordance with the ${ }^{68} \mathrm{Ga}$-radiolabelling conditions used in our clinical routine facilities $(\mathrm{pH} 4.5)$ This also allowed us to compare the ${ }^{68} \mathrm{Ga}$ results directly to the radiolabelling results for ${ }^{89} \mathrm{Zr}$, which were also performed at $\mathrm{pH} 7.4$. In brief, better radiolabelling results were achieved at $\mathrm{pH} 4.5$ than at $\mathrm{pH} 7.4$. For the latter $\mathrm{pH}$, radiolabelling yields were $22-40 \%$ for chelators 1,2 \& 3 . However, complete complexation of ${ }^{68} \mathrm{Ga}^{3+}$ could not be achieved at RT and pH 4.5 within a reasonable reaction time for the shortlived radiometal (Table 1). Unlike in the case of ${ }^{89} \mathrm{Zr}$, an elevated temperature $\left(95^{\circ} \mathrm{C}\right)$ was necessary to accomplish quantitative ${ }^{68} \mathrm{Ga}$-radiolabelling. Interestingly, these findings are in contrast with results by Tsionou et al., who reported quantitative ${ }^{68} \mathrm{Ga}$-radiolabelling of DFO at room temperature within 10 minutes at slightly different $\mathrm{pH}$ in ammonium acetate buffer.[40]

Table 1. Radiolabelling of DFO 1, DFO*2 and oxoDFO* 3 with ${ }^{68} \mathrm{GaCl}_{3}$ in HEPES at pH 4.5 and stability of the corresponding complexes ${ }^{68} \mathrm{Ga}-\mathbf{1 , 2 , 3}(n=2)$.

\begin{tabular}{lcccc}
\multicolumn{1}{c}{ Ligand } & $\mathrm{T}\left[{ }^{\circ} \mathrm{C}\right]$ & $\mathrm{t}[\mathrm{min}]$ & $\mathrm{RCY}[\%]$ & Intact complex [\%] ${ }^{\mathrm{a})}$ \\
\hline DFO 1 & $95^{\circ} \mathrm{C}$ & 10 & $>99$ & $77 \pm 1 / 62 \pm 1$ \\
DFO 1 & $\mathrm{RT}$ & 120 & 81 & - \\
DFO* 2 & $95^{\circ} \mathrm{C}$ & 10 & $98 \pm 1$ & $78 \pm 3 / 58 \pm 2$ \\
DFO* 2 & $\mathrm{RT}$ & 120 & $89 \pm 7$ & - \\
oxoDFO* 3 & $95^{\circ} \mathrm{C}$ & 10 & $>99$ & $51 \pm 5 / 37 \pm 2$ \\
oxoDFO* 3 & $\mathrm{RT}$ & 120 & $75 \pm 5$ & - \\
\hline
\end{tabular}


a) Values after incubation for $1 \mathrm{~h} / 2 \mathrm{~h}$ in $5 \mathrm{mM}$ DTPA at $\mathrm{pH} 6$.

The stability of the ${ }^{68} \mathrm{Ga}$-complexes was assessed by the same transchelation experiments with an excess of DTPA (5 mM) as described above. In general, we found that ${ }^{68} \mathrm{Ga}-\mathbf{1 , 2 , 3}$ were significantly less stable under the applied conditions than the corresponding ${ }^{89} \mathrm{Zr}$-complexes with a decreasing stability of ${ }^{68} \mathrm{Ga}-1={ }^{68} \mathrm{Ga}-2>{ }^{68} \mathrm{Ga}-3$ (Table 1). Surprisingly, approximately one third of the radiometal was found already transchelated to the challenging chelator DTPA for ${ }^{68} \mathrm{Ga}-1$ after $2 \mathrm{~h}$, although ${ }^{68} \mathrm{Ga}$-complexes of DFO 1 conjugated to peptides and proteins have been reported to be stable in vitro and in vivo.[36,35,34,40] Transchelation experiments in vitro are appropriate for a relative comparison of the stability of different (radio)metal complexes but only of limited value to predict their stability in vivo.

\section{Conclusion}

In this proof of concept study, we report the first ${ }^{89} \mathrm{Zr}$-labelling of the water-soluble, octadentate chelator oxoDFO* 3. Quantitative complexation of ${ }^{89} \mathrm{Zr}$-oxalate was achieved at $\mathrm{RT}$ and $\mathrm{pH} 7.4$ within $2 \mathrm{~h}$, reaction conditions well-suited for the radiometallation of Abs. The stability of the formed complex ${ }^{89} \mathrm{Zr}-3$ as determined in vitro by transchelation experiments was found to be similar to that of ${ }^{89} \mathrm{Zr}-2$.[30] Since the applicability of DFO* 2 for ${ }^{89} \mathrm{Zr}$ immunoPET has already been demonstrated preclinically, $[20,18]$ oxoDFO* 3 also represents a promising candidate in particular in cases where the application of co-solvents for conjugation chemistry is an issue due to the sensitivity of the protein of interest.

DFO 1, DFO* 2, and oxoDFO* 3 can also be applied for the complexation of ${ }^{68} \mathrm{Ga}$, however, elevated temperatures are required for quantitative radiolabelling and the formed products ${ }^{68} \mathrm{Ga}-1, \mathbf{2 , 3}$ exhibit a lower stability in vitro than the corresponding ${ }^{89} \mathrm{Zr}$-complexes. The 
employment of alternatives to commonly used chelators for ${ }^{68} \mathrm{Ga}$-labeling of biological molecules[40] has been reported to be beneficial in certain cases[35] and thus, further studies are warranted.

In depth investigations towards the application of bifunctional versions of oxoDFO*3[25] for the ${ }^{89} \mathrm{Zr}$-labelling of proteins and antibodies including in vivo testing have now become justified by our proof-of-concept study. Efforts to raise funds for the preclinical evaluation of

${ }^{89} \mathrm{Zr}-3$ in vivo are initiated. In addition, the assessment of the suitability of the novel chelators for complexation of other (radio)metals is currently ongoing and will be reported in due time.

\section{Conflict of interest}

Thomas Mindt and Gilles Gasser are co-inventors on pending patent applications describing DFO* and its derivatives. These patent applications are owned by the University of Zurich and the University of Basel.The patent owners have granted an exclusive license to the company ABX Advanced Biochemicals Compounds. The inventors are unrelated to this company.

\section{Supporting information}

Additional experimental material (HPLC chromatograms, iTLC pictures, MS spectra, stability data and general notes) is available at http//:doi.xxxxxxxxxxxxxxxxxxxxxx

\section{References}

1. Barbet J, Bardies M, Bourgeois M, Chatal JF, Cherel M, Davodeau F, Faivre-Chauvet A, Gestin JF, Kraeber-Bodere $F$ (2012) Radiolabeled antibodies for cancer imaging and therapy. Methods in molecular biology (Clifton, NJ) 907:681-697.

2. Brandt M, Cardinale J, Aulsebrook ML, Gasser G, Mindt TL (2018) An Overview of PET Radiochemistry, Part 2: Radiometals. Journal of nuclear medicine : official publication, Society of Nuclear Medicine 59 (10):1500-1506.

3. McInnes LE, Rudd SE, Donnelly PS (2017) Copper, gallium and zirconium positron emission tomography imaging agents: The importance of metal ion speciation. Coordination Chemistry Reviews 352:499-516. 
4. Bensch F, van der Veen EL, Lub-de Hooge MN, Jorritsma-Smit A, Boellaard R, Kok IC, Oosting SF, Schröder CP, Hiltermann TJN, van der Wekken AJ, Groen HJM, Kwee TC, Elias SG, Gietema JA, Bohorquez SS, de Crespigny A, Williams S-P, Mancao C, Brouwers AH, Fine BM, de Vries EGE (2018) 89Zr-atezolizumab imaging as a non-invasive approach to assess clinical response to PD-L1 blockade in cancer. Nature Medicine 24 (12):1852-1858.

5. Dijkers ECF, Kosterink JGW, Rademaker AP, Perk LR, van Dongen GAMS, Bart J, de Jong JR, de Vries EGE, Lub-de Hooge MN (2009) Development and Characterization of Clinical-Grade 89ZrTrastuzumab for HER2/neu ImmunoPET Imaging. 50 (6):974-981.

6. Yoon JT, Longtine MS, Marquez-Nostra BV, Wahl RL (2018) Evaluation of Next-Generation AntiCD20 Antibodies Labeled with 89Zr in Human Lymphoma Xenografts. Journal of nuclear medicine : official publication, Society of Nuclear Medicine 59 (8):1219-1224.

7. Bahce I, Huisman MC, Verwer EE, Ooijevaar R, Boutkourt F, Vugts DJ, van Dongen GA, Boellaard R, Smit EF (2014) Pilot study of 89Zr-bevacizumab positron emission tomography in patients with advanced non-small cell lung cancer. EJNMMI research 4 (1):35-35.

8. Ryman JT, Meibohm B (2017) Pharmacokinetics of Monoclonal Antibodies. CPT Pharmacometrics Syst Pharmacol 6 (9):576-588.

9. Carmon KS, Azhdarinia A (2018) Application of Immuno-PET in Antibody-Drug Conjugate Development. Mol Imaging 17:1536012118801223-1536012118801223.

10. van Dongen GA, Visser GW, Lub-de Hooge MN, de Vries EG, Perk LR (2007) Immuno-PET: a navigator in monoclonal antibody development and applications. The oncologist 12 (12):1379-1389. 11. Racow EE, Kreinbihl JJ, Cosby AG, Yang Y, Pandey A, Boros E, Johnson CJ (2019) General Approach to Direct Measurement of the Hydration State of Coordination Complexes in the Gas Phase: Variable Temperature Mass Spectrometry. Journal of the American Chemical Society 141 (37):14650-14660. 12. Adams CJ, Wilson JJ, Boros E (2017) Multifunctional Desferrichrome Analogues as Versatile 89Zr(IV) Chelators for ImmunoPET Probe Development. Molecular Pharmaceutics 14 (8):2831-2842. 13. Holland JP, Divilov V, Bander NH, Smith-Jones PM, Larson SM, Lewis JS (2010) 89Zr-DFO-J591 for immunoPET of prostate-specific membrane antigen expression in vivo. Journal of nuclear medicine : official publication, Society of Nuclear Medicine 51 (8):1293-1300.

14. Heskamp S, Raavé R, Boerman O, Rijpkema M, Goncalves V, Denat F (2017) 89Zr-ImmunoPositron Emission Tomography in Oncology: State-of-the-Art 89Zr Radiochemistry. Bioconjugate Chemistry 28 (9):2211-2223.

15. Guérard F, Beyler M, Lee YS, Tripier R, Gestin JF, Brechbiel MW (2017) Investigation of the complexation of natZr(iv) and $89 \mathrm{Zr}$ (iv) by hydroxypyridinones for the development of chelators for PET imaging applications. Dalton Transactions 46 (14):4749-4758.

16. Tieu W, Lifa T, Katsifis A, Codd R (2017) Octadentate Zirconium(IV)-Loaded Macrocycles with Varied Stoichiometry Assembled From Hydroxamic Acid Monomers using Metal-Templated Synthesis. Inorganic chemistry 56 (6):3719-3728.

17. Patra M, Bauman A, Mari C, Fischer CA, Blacque O, Haussinger D, Gasser G, Mindt TL (2014) An octadentate bifunctional chelating agent for the development of stable zirconium-89 based molecular imaging probes. Chemical Communications 50 (78):11523-11525.

18. Vugts DJ, Klaver C, Sewing C, Poot AJ, Adamzek K, Huegli S, Mari C, Visser GW, Valverde IE, Gasser G, Mindt TL, van Dongen GA (2017) Comparison of the octadentate bifunctional chelator DFO*-pPheNCS and the clinically used hexadentate bifunctional chelator DFO-pPhe-NCS for 89Zr-immuno-PET. Eur J Nucl Med Mol Imaging 44 (2):286-295.

19. Rudd SE, Roselt P, Cullinane C, Hicks RJ, Donnelly PS (2016) A desferrioxamine B squaramide ester for the incorporation of zirconium-89 into antibodies. Chemical Communications 52 (80):1188911892.

20. Berg E, Gill H, Marik J, Ogasawara A, Williams SP, van Dongen G, Vugts DJ, Cherry SR, Tarantal AF (2019) Total-body PET and highly stable chelators together enable meaningful (89)Zr-antibody-PET studies up to 30 days post-injection. J Nucl Med; https://doi.org /10.2967/jnumed.119.230961. 
21. Batista ANL, Batista Jr JM, Bolzani VS, Furlan M, Blanch EW (2013) Selective DMSO-induced conformational changes in proteins from Raman optical activity. Physical Chemistry Chemical Physics 15 (46):20147-20152.

22. Melnikova YI, Odintsov SG, Kravchuk ZI, Martsev SP (2000) Antigen-binding activity of monoclonal antibodies after incubation with organic solvents. Biochemistry Biokhimiia 65 (11):1256-1265

23. Richardson-Sanchez T, Tieu W, Gotsbacher MP, Telfer TJ, Codd R (2017) Exploiting the

biosynthetic machinery of Streptomyces pilosus to engineer a water-soluble zirconium(iv) chelator. Organic \& Biomolecular Chemistry 15 (27):5719-5730.

24. Brown CJM, Gotsbacher MP, Codd R (2020) Improved Access to Linear Tetrameric Hydroxamic Acids with Potential as Radiochemical Ligands for Zirconium-89 PET Imaging, J Australian Journal of Chemistry. https://doi.org/10.1071/CH19518

25. Briand M, Aulsebrook ML, Mindt TL, Gasser G (2017) A solid phase-assisted approach for the facile synthesis of a highly water-soluble zirconium-89 chelator for radiopharmaceutical development. Dalton Transactions 46 (47):16387-16389.

26. Holland JP (2020) Predicting the Thermodynamic Stability of Zirconium Radiotracers. Inorganic chemistry 59(3):2070-2082.

27. Vanasschen C, Brandt M, Ermert J, Coenen HH (2016) Radiolabelling with isotopic mixtures of $52 \mathrm{~g} / 55 \mathrm{Mn}(\mathrm{II})$ as a straight route to stable manganese complexes for bimodal PET/MR imaging.

Dalton transactions (Cambridge, England : 2003) 45 (4):1315-1321.

28. Deri MA, Ponnala S, Zeglis BM, PohI G, Dannenberg JJ, Lewis JS, Francesconi LC (2014) Alternative chelator for (8)(9)Zr radiopharmaceuticals: radiolabeling and evaluation of 3,4,3-(LI-1,2-HOPO). Journal of medicinal chemistry 57 (11):4849-4860.

29. Zeglis BM, Lewis JS (2011) A practical guide to the construction of radiometallated bioconjugates for positron emission tomography. Dalton Transactions 40 (23):6168-6195. doi:10.1039/CODT01595D 30. Patra M, Bauman A, Fischer C, Mari C, Gasser G, Mindt T DFO*; A novel octadentate BFCA for zirconium-89. Nuclear Medicine and Biology 41 (7):634.

31. Bartal AH, Lavie E, Boazi M, Weininger J, Bitton M, losilevsky G, Front D, Hirshaut $Y$, Robinson $E$ (1987) Human sarcoma-associated murine monoclonal antibody labeled with indium-111, gallium-67, and iodine-125. NCl monographs : a publication of the National Cancer Institute (3):153-155.

32. Koizumi M, Endo K, Kunimatsu M, Sakahara H, Nakashima T, Kawamura Y, Watanabe Y, Saga T, Konishi J, Yamamuro T, Hosoi S, Toyama S, Arano Y, Yokoyama A (1988) 67Ga-labeled Antibodies for Immunoscintigraphy and Evaluation of Tumor Targeting of Drug-Antibody Conjugates in Mice. Cancer Research 48 (5):1189-1194.

33. Motta-Hennessy C, Eccles SA, Dean C, Coghlan G (1985) Preparation of 67Ga-labelled human IgG and its Fab fragments using desferoxamine as chelating agent. European Journal of Nuclear Medicine $11(6): 240-245$.

34. Oroujeni M, Garousi J, Andersson KG, Lofblom J, Mitran B, Orlova A, Tolmachev V (2018) Preclinical Evaluation of [(68)Ga]Ga-DFO-ZEGFR:2377: A Promising Affibody-Based Probe for Noninvasive PET Imaging of EGFR Expression in Tumors. Cells 7 (9):141.

35. Kaeppeli SAM, Schibli R, Mindt TL, Behe M (2019) Comparison of desferrioxamine and NODAGA for the gallium-68 labeling of exendin-4. EJNMMI Radiopharm Chem 4:9.

https://doi.org/10.1186/s41181-019-0060-9

36. Bauman A, Valverde IE, Fischer CA, Vomstein S, Mindt TL (2015) Development of 68Ga- and 89ZrLabeled Exendin-4 as Potential Radiotracers for the Imaging of Insulinomas by PET. Journal of nuclear medicine : official publication, Society of Nuclear Medicine 56 (10):1569-1574.

37. Petrik M, Vlckova A, Novy Z, Urbanek L, Haas H, Decristoforo C (2015) Selected 68Ga-

siderophores versus $68 \mathrm{Ga}$-colloid and 68Ga-citrate: biodistribution and small animal imaging in mice. Biomedical papers of the Medical Faculty of the University Palacky, Olomouc, Czechoslovakia 159 (1):60-66.

38. Petrik $M$, Haas $H$, Schrettl $M$, Helbok A, Blatzer $M$, Decristoforo $C(2012)$ In vitro and in vivo evaluation of selected $68 \mathrm{Ga}$-siderophores for infection imaging. Nuclear medicine and biology 39 (3):361-369. 
39. Bauwens M, Chekol R, Vanbilloen H, Bormans G, Verbruggen A (2010) Optimal buffer choice of the radiosynthesis of (68)Ga-Dotatoc for clinical application. Nuclear medicine communications 31 (8):753-758.

40. Tsionou MI, Knapp CE, Foley CA, Munteanu CR, Cakebread A, Imberti C, Eykyn TR, Young JD, Paterson BM, Blower PJ, Ma MT (2017) Comparison of macrocyclic and acyclic chelators for gallium68 radiolabelling. RSC Advances 7 (78):49586-49599.

\section{Graphical abstract}

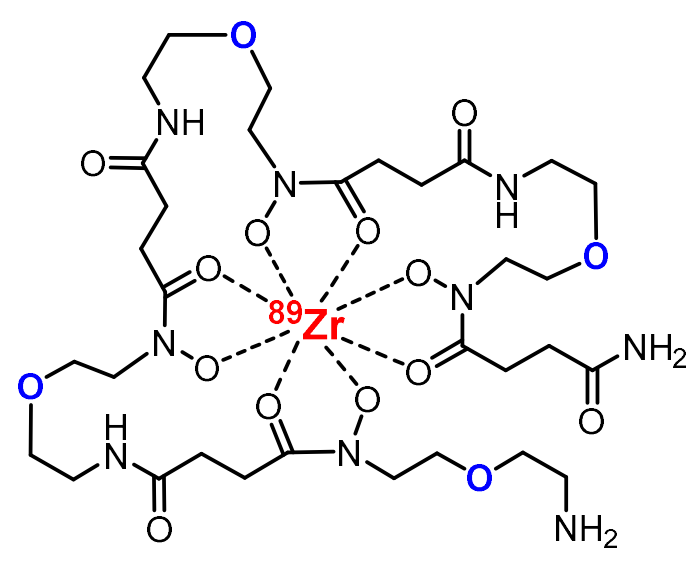

The water-soluble, octadentate chelator oxoDFO* provides stable complexes with the positron emitter Zirconium-89. The radiolabelling can be performed at room temperature and neutral $\mathrm{pH}$ and thus, oxoDFO* represents a promising chelator for applications in immunoPET. 